\title{
The Social Dimension and University Rankings
}

\author{
José María Nyssen
}

\section{The Quality of Higher Education in University and Its Link to the Social Dimension}

The concept of university quality and a number of initiatives set up in order to improve this quality in the European Higher Education Area (EHEA) serve the particular objectives that have been assigned to universities by society. Therefore, "quality criteria must reflect the overall objectives of higher education" (UNESCO 2009a).

These objectives, among others, are focused on the key role of a Higher Education oriented to increase social and human development and also to give its citizens "the necessary competencies to face the challenges of the new millennium, together with an awareness of shared values and belonging to a common social and cultural space" (European Ministers Responsible for Higher Education 1999).

A number of relevant supranational institutions have stated a broad scope of aspects related to the social dimension to which Higher Education has been invited to be fully involved for their development.

The most recent UNESCO Communiqués focused on Higher Education (1998, 2009a) stress the important role that this Education should play worldwide, not only for economic but also for social development. The above mentioned Higher Education objectives are guided by the commitment to leading society to generate global knowledge so as to address global challenges of the utmost importance (UNESCO 2009a) - for instance, developing quality programmes geared to bridging skill gaps for advancing sustainable development objectives (United Nations 2012), and they "should aim at the creation of a new society consisting of

J. M. Nyssen ( $\square)$

National Agency for Quality Assessment and Accreditation of Spain,

ANECA, Madrid, Spain

e-mail: jmnyssen@aneca.es

(C) The Author(s) 2018

A. Curaj et al. (eds.), European Higher Education Area: The Impact of Past and Future Policies, https://doi.org/10.1007/978-3-319-77407-7_11 
highly cultivated, motivated and integrated individuals, inspired by love for humanity and guided by wisdom" (UNESCO 1998).

These Communiqués are in keeping with an idea of quality education as "an effective means to fight poverty, build democracies, and foster peaceful societies" (UNESCO 2005). Actually, the Framework for the UN Decade of Education for Sustainable Development (UNESCO 2006) as a precedent of the current UN Global Education 2030 Agenda, underlined the close relationship between sustainability learning outcomes and quality education.

In the European context, along with supranational institutions like European Union (2010, 2012) and Council of Europe (2006, 2010), which are also concerned about the impact of Higher Education in improving social development, the Bologna Process and the EHEA have played an important role by defining the "social dimension".

The Bologna Declaration (European Ministers Responsible for Higher Education 1999), that marked the beginning of the construction of the EHEA, put forward an overview of key goals for the society in which Higher Education can contribute to their achievement. Therefore, these declarations identified a set of aspects linked to the development of economy and labour market, and also defined the cultural, intellectual and scientific progress in an international context. Furthermore, taking a historical perspective into account, the importance of some aspects closely related to social development (e.g. democratic citizenship, intercultural respect, peace, international cooperation, etc.) has been stressed.

On the basis of this Declaration, the "social dimension" in the Bologna Process was mentioned by European ministers for the first time in the Prague Communiqué (European Ministers Responsible for Higher Education 2001) two years later. This "social dimension" on that phase of the Process still had to be defined in its objectives, scope and contents, but there was anticipated concern in a number of aspects embedded in its scope, including mobility and its relationship with democratic values, diversity of cultures and languages, and the diversity of the higher education systems. Likewise, linked to the lifelong learning strategy and equity in the access to tertiary education, attention has been paid to improve social cohesion, equal opportunities and the quality of life.

But it is during the Ministerial Conference of Bergen (European Ministers Responsible for Higher Education 2005) when an initial definition for the "social dimension" in this European framework was created, and within this definition, the main objective of "making quality higher education equally accessible to all, and stress the need for appropriate conditions for students so that they can complete their studies without obstacles related to their social and economic background".

Bearing in mind all these elements, the London Communiqué (European Ministers Responsible for Higher Education 2007) presented in a more precise manner the Bologna Process vision about the aims of Higher Education, including "preparing students for life as active citizens in a democratic society; preparing students for their future careers and enabling their personal development; creating and maintaining a broad, advanced knowledge base; and stimulating research and innovation". And according to the above-mentioned vision, it went further than the 
previous Communiqué in the range of purposes of the "social dimension" stressing not only equity aspects but those related to democratic citizenship, sustainability and regard for diversity.

Finally, the recent Yerevan Communiqué (European Ministers Responsible for Higher Education 2015), that is aligned with a vision of the "social dimension" mainly focused on aspects of equity and reduction of inequalities, stated on the previous Ministerial Conferences (European Ministers Responsible for Higher Education 2009, 2010, 2012), also lays down a "renewed vision" of the EHEA and its role in addressing serious challenges, in which democratic citizenship and human rights issues have been outlined.

In conclusion, despite some differences in the scope of the social dimension fostered by these supranational frameworks, all in all, they underline the importance of this dimension and furthermore reflect a common interest in its strengthening.

\section{The Impact of University Rankings in Defining "Quality" in Higher Education}

If there is any consensus on rankings, it is on their considerable and growing protagonism as "quality measure" instruments, despite the weaknesses known to be associated with them (Altbach 2006: 77; Altbach et al. 2009: 11; Gutiérrez-Solana and Valle 2013: 27; Hazelkorn 2013a: 49-55, 59, 2013b: 85, 87; Marginson 2007: 131; Martínez 2013: 61; Rodríguez 2013: 151, 153; Saisana and D’Hombres 2008: 5-6; Salmi and Saroyan 2007: 82) and the mismatches between indicators of league tables and indicators of educational quality (Salmi and Saroyan 2007: 85). Attention is repeatedly paid in the literature to the problems found in these resources; for example, conditioning derived from: lack of data for calculation of fundamental aspects; lack of rigour in the methodology employed; lack of information and transparency in this methodology and in the dissemination of results; etc.

This work will not attempt a broad or complete discussion of the lively debate that has in recent years surrounded the proliferation of university rankings, though those interested in such a discussion will find it in such works as Dill and Soo (2005), Usher and Savino (2006), Marope et al. (2013) and Rodríguez (2013: 151265). Rather, we will focus here on setting forth some key "narratives" of the idea of quality linked to these instruments that aim prioritize a range of aspects still under discussion.

The literature reveals a number of advantages and strengths of the facilitating character of university rankings:

- In their synthesis, university rankings "simplify" the information on the current state of higher education for various of the interested parties, supplying, in the strongest terms, a verdict on the quality, excellence or distinction of institutions or educational programs (in this respect, see Hazelkorn 2013a: 49; Marginson 
and van der Wende 2007a: 55; Marginson 2007: 131; Marope and Wells 2013: 9; Rauhvargers 2011: 12; Rodríguez 2013; Safón 2013: 73; Santiago et al. 2008, vol. II: 254,279$)$.

- They also prioritize and make public information presumably "of interest" on certain aspects of institutions and programs of higher education (Buela-Casal et al. 2007: 2; Dill and Soo 2005; Hazelkorn 2007; Federkeil 2002; Marginson and van der Wende 2007b; Marope and Wells 2013: 12; Rodríguez 2013; Vlăsceanu et al. 2004: 52).

On the other hand, however, there is a notable conditioning derived from a reductionist construction of the concept of "quality" in university rankings that is not adjusted to the diversity of the demands that society places on Higher Education (Altbach et al. 2009: 11; Ellis and Weekes 2008: 494; EU High Level Group on the Modernisation of Higher Education 2013: 36; Hazelkorn 2013a: 52-53; Marope and Wells 2013: 13; Rodríguez 2013; Scott 2013; Usher and Savino 2006, 2007). And among the above-mentioned demands, it is important to take into account those relating to the social dimension.

Habitually, the selection and weighing of "quality" - configuring indicators in international rankings - has the impact of prioritizing indicators associated with size and age of the institution, and with the volume of scientific research and production, fundamentally in English, all of which implies, a priori, the predominance of a particular institutional profile found mostly in a reduced group of countries (Altbach 2006: 79; Marginson and van der Wende 2007a: 62; Rauhvargers 2013: 19; Rodríguez 2013; Saisana and D'Hombres 2008: 8; Salmi 2009: 17; Salmi and Saroyan 2007: 84-85; Santiago et al. 2008, vol. I: 279; UNESCO 2009b: 25; van der Wende 2008: 60, 62). In short, there is a strong bias in favour of research universities, and less attention is paid to good practices of teaching and learning or to the regional engagement of the universities. "Institutional diversity", in objectives and ways of reaching them, is radically diminished in terms of its compatibility with this particular idea of "quality". Therefore, it would be difficult for any university not adjusted to this model to reach an advantageous position in relation to it. Despite this, all universities in the international context are, explicitly or implicitly, examined and evaluated through this prism of quality, which scarcely takes into consideration other enriching and relevant aspects nor any historical, disciplinary, contextual or cultural circumstances.

Another example of this is the type of expression used to denote the ideal position to attain, that of the highest esteem and value. This is frequently encapsulated in terms such as quality, excellence, World-class, success at a Global scale. However, the use of these concepts is habitually criticized as mistaking the part for the whole and for making an attempt to express complex concepts and objectives with very few and not always well-chosen aspects. Furthermore, these terms suggest an ideal state of purity, supposedly desirable in and of itself, though not effectively delineated into substantive components fundamental to higher education objectives such as social development or attainment of capabilities (Nussbaum 2012) by individuals in society. 
In this sense, two points are of further importance:

- Firstly, the prioritisation of certain aspects established by the organisations and bodies setting the rankings disregards any accordance to the set of Higher Education objectives outlined by EHEA and organisations such as UNESCO. Therefore, such prioritisations can lead to the reorientation of Higher Education objectives ignoring the agreements of member states in this respect (some authors qualify this prioritisation as arbitrary or even to be in self-interest).

- Secondly, the idea of "quality" used in rankings, particularly in reference to the concrete aspects supporting it, does not correspond to a democratic criterion, but nonetheless it strongly affects Higher Education as a public good (United Nations 2010: 9) because university systems as a whole cannot escape being affected by the strong effects of rankings in the shaping of this idea, which is not including important demands in society.

Thus, there is a notable change in the behaviour of universities resulting from the effects of these evaluation resources and their results.

However, beyond the presumed virtues of rankings, and considering all of the problems we have seen, might there be an additional element explaining the enormous and growing influence these resources exercise on the policies of Higher Education?

A partial answer may be that these rankings, on top of everything else, offer something "of interest" which other resources do not offer in such evident and immediate form: participation in the social dynamics of self-esteem and explicit public recognition (Rauret 2013: 90; Rodríguez 2013: 152).

More concretely, rankings bestow public recognition upon universities, academic programs, and people connected to them (for example, research personnel or students), recognition which, both in and of itself and because of its frequent consequences, creates an incentive to upgrade in: (a) certain assessed factors, and (b) the supply of visibility - conveying information on advances in these factors (Hämäläinen et al. 2003: 12; Kaiser et al. 2007: 40; Marginson and van der Wende 2007a, b: 326; Marope and Wells 2013: 17; van der Wende 2008: 64; Westerheijden et al. 2009: 80).

It is clear that this pursuit of social recognition is no simple allegorical exercise, as this recognition is seen as a means towards access to resources and opportunities (Clarke 2007; Martínez 2013: 63; Liu 2013: 35) in a competitive institutional field.

With rankings, the better-classified institutions obtain, in many cases, superior resources and more prestigious professionals. Their students frequently have access to better jobs and contacts in higher positions with more responsibility. In short, there is a clear relationship between the idea mentioned above and capital $^{1}$ growth in a type of Matthew effect (Merton 1968, 1988; and also in this respect Altbach et al. 2009: 11, 32; Archer 2007: 641; Hazelkorn 2007: 4-5; ESU 2009: 39); so that institutions in better positions at the start tend to garner resources that allow them to maintain their positions.

\footnotetext{
1“Capital" in a wider sense such as that used by P. Bourdieu (2000).
} 
Also importantly, the dynamic of the pursuit of social recognition flourishes in the university context at various levels, reaching a point where it displaces other, presumably objectives of higher priority, and becomes essentially predominant. Put another way, demonstrating its own value itself becomes a primary objective over other elements.

On top of this, the semantic and formal elements of the university ranking narrative also convey a value judgment. For example, the highest ranked institutions are frequently alluded to as "elite" institutions, as opposed to "massified" institutions. This discourse invites a reading of the university reality in terms of the dichotomy elite/masses (Altbach et al. 2009: 84; Bjarnason et al. 2009: 15; Hazelkorn 2013a: 49, 2013b: 86; Marope and Wells 2013: 17; Rauhvargers 2013: 17; Santiago et al. 2008, vol. I: 308) and assumes an aspiration on the part of all universities to reach a state of identification with the elite and flee as far as possible from any connotation of "massification".

However, instead of viewing the university world through the lens of "massification", why not interpret this reality in other terms? For example, given the challenge of making a quality higher education accessible to an always greater and more diverse number of people all over the world, are not the very universities ranked at the "massification" extreme of the scale contributing in greater measure than those considered "elite" towards the goal of making education accessible to those of economically disfavoured social origin?

Further than this, there is a key conclusion. Rankings are oriented toward making social recognition possible through the valuation of very particular aspects and also map out a tangible route to its procurement, centred on improvements in these aspects. Thus, rankings are a powerful conduit not only for the public display of recognition but also for determining which efforts are to be made in its pursuit. For instance, some universities are using league tables for goal-setting purposes (Salmi and Saroyan 2007: 89).

In this lively debate about university rankings, an important question arises: can rankings be used in a constructive way? (Salmi and Saroyan 2007: 88). Given the impact of university rankings and the great importance of advancing in a range of social dimension goals through Higher Education, what if university rankings could foster the commitment of universities to better their outcomes as regards social dimension?

\section{The Commitment of the University with the Social Dimension Through the Quality of Higher Education: A Proposal to Include University Rankings}

Five of the most currently followed international rankings were examined in order to verify whether, among the substantial objectives of higher education they contemplate, they include, to any extent, in their idea of "quality" any aspects related to social development through Higher Education (see Table 1). 
Table 1 Social development aspects in international rankings

\begin{tabular}{|c|c|}
\hline University ranking & Social development aspects \\
\hline QS World University Rankings ${ }^{\circledR}$ & Labour market issues \\
\hline $\begin{array}{l}\text { Academic Ranking of World Universities- } \\
\text { ARWU }\end{array}$ & Labour market issues; relationship to industry \\
\hline \multicolumn{2}{|l|}{ Ranking Web of Universities (Webometrics) } \\
\hline $\begin{array}{l}\text { Times Higher Education World University } \\
\text { Rankings (The World University Rankings) }\end{array}$ & Relationship to industry \\
\hline U-Multirank & $\begin{array}{l}\text { Labour market issues; relationship to industry; } \\
\text { gender equity; community service learning; } \\
\text { regional engagement }\end{array}$ \\
\hline
\end{tabular}

The main conclusion drawn from this analysis is that four of these rankings do not contemplate indicators directly related to diverse aspects of social development, with the sole exception of economic indicators connected to labour market issues and to the relationship between universities and industry. Only U-Multirank has added a set of indicators relating to the social dimension, including issues such as regional engagement (e.g. BA theses with regional organisations ${ }^{2}$; MA theses with regional organisations ${ }^{3}$; Regional joint publications ${ }^{4}$; etc.), and more recently, gender equity (e.g. Percentage of female students ${ }^{5}$; Female students bachelor ${ }^{6}$; Female students master ${ }^{7}$; Female academic staff $^{8}$; Female professors ${ }^{9}$ ) and community service learning. ${ }^{10}$

Nonetheless, incipient initiatives are already working toward the inclusion in university rankings of indicators tied to a bigger number of aspects through which higher education can influence social development; notably, among others:

- the "Call to Action" Communiqué (Talloires Network 2014): in which leaders from 134 universities and higher education partner institutions from 40 countries across the globe encourage the global university ranking systems "to take civic

\footnotetext{
${ }^{2}$ Degree theses of bachelor graduates done in cooperation with organisations (industry, public, non-profit organisations) in the region.

${ }^{3}$ Degree theses of master graduates done in cooperation with organisations (industry, public, non-profit organisations) in the region.

${ }^{4}$ The percentage of department's research publications that list at least one co-author with an affiliate address in the same spatial region (within a distance of $50 \mathrm{~km}$ from the university).

${ }^{5}$ Percentage of female students enrolled at the department.

${ }^{6}$ The number of female students enrolled in bachelor programmes as a percentage of the total enrolments in bachelor programmes.

${ }^{7}$ The number of female students enrolled in master programmes as a percentage of the total enrolments in master programmes.

${ }^{8}$ The number of female academic staff as a percentage of the total number of academic staff.

${ }^{9}$ The number of female professors as a percentage of the total number of professors.

${ }^{10}$ The percentage of credits given in service-learning activities, in relation to the total number of credits.
} 
engagement seriously and to reduce the negative effects of the ranking systems on the public service responsibilities of higher education";

- QS Stars ratings (QS Quacquarelli Symonds Limited 2014): a rating system that takes into account a number of factors that are often overlooked in university rankings, including in the "Social Responsibility" and "Inclusiveness" a set of criteria, such as "Community investment and development", "Charity work and disaster relief", "Regional human capital development", "Environmental impact", "Scholarships and bursaries", "Disabled access", "Gender balance" and "Low-income outreach".

- "UI Green Metric" (Universitas Indonesia) and "Business Education for Sustainable Development-BESD” (Spitzeck and Siegenthaler 2007: 52-54): both value-driven rankings that aim at addressing sustainable development through league tables and a set of indicators focused on a picture on how the university is responding to or dealing with the issues of sustainability, such as transport, water usage, waste management, infrastructures, energy and the role of education by creating the new generation concern with sustainability issues.

This work, that is part of a wider investigation, aims to: (1) encourage universities to work to improve their situation over a range of aspects of the social dimension; (2) publicly value the work of universities on this matter; and (3) provide students and society with more complete, accurate and balanced information on university outcomes according to the Higher Education objectives outlined by EHEA and UNESCO.

Presented here as a complement to the above-mentioned valuable initiatives is a proposal to enrich university rankings, so that these, in turn, would incentivize a higher education more committed to social development in its various facets. Therefore, the proposal aims at reconciling social dimension objectives for higher education - set out by EHEA and UNESCO — with the persuasive power of rankings.

As a result of going through two main sources of information, a number of key aspects related to the social dimension and the Higher Education missions have been identified. This work has analysed, on the one hand, the institutional communiqués and official statements about Higher Education challenges published by EHEA, UNESCO, United Nations, Council of Europe and European Union from 1998 to 2015 and, on the other hand, the content of the Delphi study responses given by 214 experts (higher education specialists, rectors and other university employees, public policy makers and members of civil society involved in various different areas of development) from 80 countries, who were invited to participate in this study set up by Global University Network for Innovation (Lobera and Secretariado GUNI 2008) that aimed to gather the diverse participant's approaches to the role of Higher Education for social and human development.

Far from a restricted idea of social dimension, the proposal that is presented is based on a more comprehensive idea of this social dimension according to the objectives of Higher Education stated by the above-mentioned institutions. 
The proposal is divided into two parts:

- The first part of the proposal offers a series of indicators complementary to those already existing in international university rankings, so that these rankings incentivize attention to certain objectives tied to particular aspects of social development and, at the same time, serve as a guide for channelling the efforts of agents involved in the pursuit of these objectives.

- The second part of the proposal, subsequent to this, draws the main lines of future strategy for the strengthening, improvement, and recognition of the quality of university rankings more clearly conscious of these objectives and of their potential repercussions.

University rankings are not, a priori, forced to value a set of circumscribed dimensions of higher education - such as "scientific production" in certain journals -but their idea of "quality" may be shaped, at least in part, by the recognition of certain aspects of common interest related to social development.

Due to the great limitations in available data, this pilot proposal of indicators is meant to be a modest but realistic beginning, with every indicator open to discussion and to adaptation for incorporation in any nationally or internationally recognised university ranking (see Table $2^{11}$ ).

Centring our attention on the final five indicators in this proposal, which measure the presence in curricula of substantive learning outcomes directly tied to diverse facets of social development, as stated by Salmi (2009: 72-73), it is important to point out the debate on measuring learning outcomes at the tertiary education level as a recognition that "excellence is not only about achieving outstanding results with outstanding students but ought perhaps to be also measured in terms of how much added value is given by institutions in addressing the specific learning needs of an increasingly diverse student population".

Actually, certain higher education objectives can only be reached if the substantive content joined to them is nurtured and empowered in a similar way as occurs now with other content more closely tied to professional development.

Beyond the mere proposal of new indicators open to being included in current university rankings, the next steps would be:

- First, carry out a pilot study contemplating the calculation of indicator results as far as available data sources allow.

- Likewise, confronting the lack of or inconsistency in data, document each case and call it to the attention of the entities responsible (or potentially responsible) for the sources of data.

- Second, submit this set of indicators and results to discussion by different stakeholders involved so that, on the one hand, the proposal is improved in specific aspects and, on the other hand, these stakeholders are encouraged to reflect on the importance of the relationship between Higher Education and social development.

\footnotetext{
${ }^{11}$ More detailed information on the indicators and their data sources is available on request.
} 
Table 2 Set of indicators

\begin{tabular}{|c|c|}
\hline ty & $\begin{array}{l}\text { - Annual contribution of the number of university graduates from recognized } \\
\text { institutions to society } \\
\text { Number of graduates from a recognized institution }{ }^{\mathrm{a}} \text { per academic year } \\
\text { Note: Level of studies according to International Standard Classification of Education } \\
\text { - ISCED } \\
\text { - Upward intergenerational mobility in education (by parents' educational } \\
\text { attainment) } \\
\text { Number of graduates from a recognized institution whose parents both have below } \\
\text { tertiary education } \\
\text { - Gender equity in completion of higher education } \\
\text { Ratio between the numbers of graduate women and men } \\
\text { Note: from a recognized institution } \\
\text { - Gender equity in composition of highest level academic staff } \\
\text { Ratio between the numbers of female and male full professors }\end{array}$ \\
\hline & $\begin{array}{l}\text { - Consideration of work on social engagement } \\
\text { Number (and level) of prizes awarded by institutions or institutional networks that are } \\
\text { recognized in the field of Social Development } \\
\text { - Leadership in actions focused on sustainable development and social engagement } \\
\text { Full member of a recognized university network focused on sustainable development } \\
\text { or social engagement and also working at that moment on a project focused on that } \\
\text { issue (published by the network) } \\
\text { - Leadership in social development projects } \\
\text { Annual amount received in order to coordinate competitive projects in the framework } \\
\text { of institutional programmes focused on social development and cooperation }\end{array}$ \\
\hline $\begin{array}{l}\text { Substantive } \\
\text { learning } \\
\text { outcomes in } \\
\text { accredited } \\
\text { university } \\
\text { degrees }^{\mathrm{b}}\end{array}$ & $\begin{array}{l}\text { - Learning outcomes in "Equity" } \\
\text { Percentage of degrees that include learning outcomes focused on "Equity" out of the } \\
\text { total number of degrees of the university (number of degrees in which their syllabuses } \\
\text { include one or more learning outcomes or competences relating to "Equity" out of the } \\
\text { total number of degrees offered by the university) c } \\
\text { - Learning outcomes in "Sustainability" } \\
\text { Percentage of degrees that include learning outcomes focused on "Sustainability" out } \\
\text { of the total number of degrees of the university } \\
\text { - Learning outcomes in "Democratic Citizenship" } \\
\text { Percentage of degrees that include learning outcomes focused on "Democratic } \\
\text { Citizenship" out of the total number of degrees of the university } \\
\text { - Learning outcomes in "Human Rights" } \\
\text { Percentage of degrees that include learning outcomes focused on "Human Rights" out } \\
\text { of the total number of degrees of the university } \\
\text { - Learning outcomes in "Cooperation and Social Engagement" } \\
\text { Percentage of degrees that include learning outcomes focused on "Cooperation and } \\
\text { Social Engagement" out of the total number of degrees of the university }\end{array}$ \\
\hline \multicolumn{2}{|c|}{$\begin{array}{l}\text { aAvailable at } \\
\text { - UNESCO Portal to Recognized Higher Education Institutions-HEIs (http://www.unesco.org/new/en/ } \\
\text { education/resources/unesco-portal-to-recognized-higher-education-institutions/) } \\
\text { - ENIC-NARIC. Recognized HEIs (http://www.enic-naric.net/recognised-heis.aspx; http://www.enic- } \\
\text { naric.net/higher-education-institution.aspx) and Quality assurance: accredited programmes (http:// } \\
\text { www.enic-naric.net/quality-assurance-accredited-programmes.aspx) } \\
\text { - Quality Agencies (INQAAHE http://www.inqaahe.org/; EQAR https://www.eqar.eu/) } \\
\text { bofficial university degrees accredited by a Quality Agency (for example, in the EHEA, the quality } \\
\text { agencies of the European Quality Agency Register-EQAR) } \\
\text { ce.g. Public information about competencies and learning outcomes included in each official degree } \\
\text { syllabus in the Spanish University System, is available at the 'Register of Universities, Centers and } \\
\text { Degrees-RUCT' website }\end{array}$} \\
\hline
\end{tabular}


- Third, integrate accepted indicators into the university rankings.

- And fourth, take progressive steps to inaugurate certification processes for university rankings.

On this last point, we are not starting from zero. For example, the objective of the IREG Ranking Audit initiative (IREG Observatory 2011) is to verify and certify that the ranking under study is professionally developed, with transparent methodology, observes best practices in its area, and responds to a need for information on the part of various agents (in particular students, higher education institutions, employers and institutional managers).

However, despite its similarities with the IREG Ranking Audit initiative (IREG Observatory, n.d.), which might suggest a complementary relationship, the project proposed here emphasizes in particular the need of bringing the bases for certifying the pertinence and quality of rankings in line with the Higher Education objectives reflected in texts endorsed by UNESCO or others of similar character in the respective fields involved in the construction of the European Area concerning us today. For this reason, substantive aspects tasked to these universities, starting with the teaching/learning process, would need to be addressed.

\section{Conclusion}

In conclusion, there is a noticeable lack of attention to the social dimension in the rankings, although the inclusion of indicators focused on this dimension is not only important but also feasible and affordable.

The main purpose of the present work is to contribute to the fostering of a range of social dimension aspects in the EHEA through a newly proposed instrument focused on the impact of current university rankings. Therefore, taking into account the important role of higher education in addressing current and future challenges, further development is needed in order to make "quality measure" tools, including university rankings, more relevant for society.

Far from ignoring the magnetism of some social dynamics linked to university rankings, such as the previously noted "simplification" or "pursuit of recognition," the immediate challenge may lie not so much in an impetuous battle against rankings as in taking advantage of their potential, making an effort to endow them with a substantiveness that favours social development in its diverse facets, encouraging its inclusion in the so-called capabilities approach (Sen 2000; Nussbaum 2007, 2012).

In short, given that university rankings are already a far-reaching reality, and bearing in mind the previous analysis of their advantages and disadvantages, it is fitting to try to ensure that their effects are, as far as possible, in the service of social objectives arising from democratic debate among a citizenry that is committed to the attainment of fundamental rights and freedoms. 


\section{References}

Altbach, P. G. (2006). International higher education: Reflections on policy and practice. Massachusetts: Center for International Higher Education, Boston College.

Altbach, P. G., Reisberg, L., \& Rumbley, L. E. (2009). Trends in global higher education: Tracking an academic revolution. A report prepared for the UNESCO 2009 world conference on higher education. Paris: UNESCO.

Archer. (2007). Diversity, equality and higher education: A critical reflection on the abuses of equity discourse within widening participation. Teaching in Higher Education, 12(5-6), 635-653.

Bjarnason, S., et al. (2009). A new dynamic: Private higher education. Paris: UNESCO.

Bourdieu, P. (2000). Poder, derecho y clases sociales. Bilbao: Desclée de Brouwer.

Buela-Casal, G., Gutiérrez-Martínez, O., Bermúdez-Sánchez, M. P., \& Vadillo-Muñoz, O. (2007). Comparative study of international academic rankings of universities. Scientometrics, 71(3), 349-365.

Clarke, M. (2007). The impact of higher education rankings on student access, choice, and opportunity. Higher Education in Europe, 32(1), 59-70.

Council of Europe. (2006). Declaration on the responsibility of higher education for a democratic culture-Citizenship, human rights and sustainability. Strasbourg: Council of Europe.

Council of Europe. (2010). Council of Europe charter on education for democratic citizenship and human rights education. Strasbourg: Council of Europe.

Dill, D. D., \& Soo, M. (2005). Academic quality, league tables, and public policy: A crossnational analysis of university ranking systems. Higher Education, 9(4), 495-533.

Ellis, G., \& Weekes, T. (2008). Making sustainability 'real': Using group-enquiry to promote education for sustainable development. Environmental Education Research, 14(4), 482-500.

EU High Level Group on the Modernisation of Higher Education. (2013). Report to the European Commission on improving the quality of teaching and learning in Europe's higher education institutions. Luxembourg: European Commission.

European Ministers Responsible for Higher Education. (1999). Bologna declaration. European Higher Education Area.

European Ministers Responsible for Higher Education. (2001). Prague Communiqué. European Higher Education Area.

European Ministers Responsible for Higher Education. (2005). Bergen Communiqué. European Higher Education Area.

European Ministers Responsible for Higher Education. (2007). London Communiqué. European Higher Education Area.

European Ministers Responsible for Higher Education. (2009). Leuven/Louvain-la-Neuve Communiqué. European Higher Education Area.

European Ministers Responsible for Higher Education. (2010). Budapest-Vienna declaration. European Higher Education Area.

European Ministers Responsible for Higher Education. (2012). Bucharest Communiqué. European Higher Education Area.

European Ministers Responsible for Higher Education. (2015). Yerevan Communiqué. European Higher Education Area.

European Union. (2010). Communication from the commission. Europe 2020: A strategy for smart, sustainable and inclusive growth. Brussels: European Union.

European Union. (2012). Resolución del Parlamento Europeo, de 20 de abril de 2012, sobre la modernización de los sistemas de educación superior en Europa. Brussels: European Union.

Federkeil. (2002). Some aspects of ranking methodology-The CHE-ranking of German universities. Higher Education in Europe, 27(4), 389-397.

Gutiérrez-Solana, F., \& Valle, A. (2013). Los avances del sistema universitario español: medir sus resultados. In V. Climent, F. Michavila, \& M. Ripollés (Eds.), Los rankings universitarios, mitos y realidades (pp. 23-41). Madrid: Tecnos. 
Hämäläinen, K., Hämäläinen, K., Dorge, A., Kaartinen-Koutaniemi, M., \& Kristoffersen, D. (2003). Benchmarking in the improvement of higher education. ENQA workshop reports 2. Helsinki: ENQA.

Hazelkorn, E. (2007). The impact of league tables and ranking systems on higher education decision making. Higher Education Management and Policy, 19(2), 1-24.

Hazelkorn, E. (2013a). How rankings are reshaping higher education. In V. Climent, F. Michavila, \& M. Ripollés (Eds.), Los rankings universitarios, mitos y realidades (pp. 49-60). Madrid: Tecnos.

Hazelkorn, E. (2013b). World-class universities or world-class systems? Rankings and higher education policy choices. In P. T. M. Marope, P. J. Wells, \& E. Hazelkorn (Eds.), Rankings and accountability in higher education. Uses and misuses (pp. 71-94). Paris: UNESCO.

IREG Observatory. (2011). IREG ranking audit manual. Warsaw: IREG. Retrieved September 3, 2017, from http://ireg-observatory.org/en/pdfy/ranking_audith_audit.pdf.

IREG Observatory. (n.d.). IREG ranking AUDIT. Retrieved September 3, 2017, from http://iregobservatory.org/en/index.php/information.

Kaiser, F., Beverwijk, J., Dassen, A., Deen, J., Jongbloed, B., \& Kaulisch, M., et al. (2007). Issues in higher education policy 2006. An update on higher education policy issues in 2006 in 10 Western countries. Enschede: CHEPS.

Liu, N. C. (2013). The academic ranking of world universities and its future direction. In P. T. M. Marope, P. J. Wells, \& E. Hazelkorn (Eds.), Rankings and accountability in higher education. Uses and misuses (pp. 23-39). Paris: UNESCO.

Lobera, J., \& Secretariado GUNI. (2008). Encuesta delphi - La educación superior para el desarrollo humano y social. In GUNI (Ed.), La Educación Superior en el Mundo 3. Educación Superior: Nuevos Retos y Roles Emergentes para el Desarrollo Humano y Social (pp. 307-331). Madrid: Mundi-Prensa.

Marginson, S. (2007). Global university rankings: Implications in general and for Australia. Journal of Higher Education Policy and Management, 29(2), 131-142.

Marginson, S., \& van der Wende, M. (2007a). Globalisation and higher education. Paris: OECD.

Marginson, S., \& van der Wende, M. (2007b). To rank or to be ranked: The impact of global rankings in higher education. Journal of Studies in International Education, 11(3-4), 306-329.

Marope, P. T. M., \& Wells, P. J. (2013). University rankings: The many sides of the debate. In P. T. M. Marope, P. J. Wells, \& E. Hazelkorn (Eds.), Rankings and accountability in higher education. Uses and misuses (pp. 7-19). Paris: UNESCO.

Marope, P. T. M., Wells, P. J., \& Hazelkorn, E. (2013). Rankings and accountability in higher education. Uses and misuses. Paris: UNESCO.

Martínez, J. (2013). La generalización del uso de las clasificaciones universitarias. In V. Climent, F. Michavila, \& M. Ripollés (Eds.), Los rankings universitarios, mitos y realidades (pp. 61-71). Madrid: Tecnos.

Merton, R. K. (1968). The Matthew effect in science. Science, 159(3810), 56-63.

Merton, R. K. (1988). The Matthew effect in science, II: Cumulative advantage and the symbolism of intellectual property. Isis, 79(4), 606-623.

Nussbaum, M. C. (2007). Las fronteras de las justicia. Consideraciones sobre la exclusión. Barcelona: Paidós.

Nussbaum, M. C. (2012). Crear capacidades. Propuesta para el desarrollo humano. Madrid: Paidós.

QS Quacquarelli Symonds Limited. (2014). QS stars: Methodology. Retrieved September 3, 2017, http://www.topuniversities.com/qs-stars/qs-stars-methodology.

Rauhvargers, A. (2011). global university rankings and their impact. EUA report on rankings 2011. Retrieved September 3, 2017, from http://www.eua.be/Libraries/Publications_ homepage_list/Global_University_Rankings_and_Their_Impact.sflb.ashx.

Rauhvargers, A. (2013). Global university rankings and their impact-Report II-EUA report on rankings 2013. Brussels: EUA. 
Rauret, G. (2013). Los rankings y las prioridades académicas. In V. Climent, F. Michavila, \& M. Ripollés (Eds.), Los rankings universitarios, mitos y realidades (pp. 86-99). Madrid: Tecnos.

Rodríguez, S. (2013). La evaluación de la calidad en la educación superior. Madrid: Síntesis.

Safón, V. (2013). ¿Existe al ranking ideal? In V. Climent, F. Michavila, \& M. Ripollés (Eds.), Los rankings universitarios, mitos y realidades. Madrid: Tecnos.

Saisana, M., \& D'Hombres, B. (2008). Higher education rankings: Robustness issues and critical assessment. How much confidence can we have in higher education rankings?. Luxembourg: Office for Official Publications of the European Communities.

Salmi, J. (2009). The challenge of establishing world-class universities. Washington DC: The World Bank.

Salmi, J., \& Saroyan, A. (2007). League tables as policy instruments: The political economy of accountability in tertiary education. In GUNI (Ed.), Higher education in the world 2007: Accreditation for quality assurance: What is at stake? (pp. 79-95). London: Palgrave MacMillan.

Santiago, P., Tremblay, K., Barsi, E., \& Arnal, E. (2008). Tertiary education for the knowledge society. Paris: OECD.

Scott, P. (2013). Ranking higher education institutions: A critical perspective. In P. T. M. Marope, P. J. Wells, \& E. Hazelkorn (Eds.), Rankings and accountability in higher education. Uses and misuses (pp. 113-127). Paris: UNESCO.

Sen, A. (2000). Desarrollo y libertad. Barcelona: Planeta.

Spitzeck, H., \& Siegenthaler, C. P. (2007). Value-driven and stakeholder-based ranking-A closer look at evaluating "education for sustainable development". Higher Education in Europe, 32 (1), 49-57.

Talloires Network. (2014). Call to action. Talloires network leaders conference, 2-4 December 2014, Cape Town, South Africa. Retrieved September 3, 2017 http://talloiresnetwork.tufts.edu/ wp-content/uploads/TNLC-Call-to-Action-final.pdf.

The European Students' Union-ESU. (2009). Equity handbook. How you and your student union can help give people equal opportunities in higher education. Brussels: European Commission.

UNESCO. (1998). World declaration on higher education for the twenty-first century: Vision and action and framework for priority action for change and development in higher education. In World Conference on Higher Education Higher Education in the Twenty-First Century: Vision and Action, 9 October 1998.

UNESCO. (2005). Contributing to a more sustainable future: Quality education, life skills and education for sustainable development. Paris: UNESCO.

UNESCO. (2006). Framework for the UN DESD international implementation scheme. Paris: UNESCO.

UNESCO. (2009a) 2009 world conference on higher education: The new dynamics of higher education and research for societal change and development (UNESCO, Paris, 5-8 July 2009), Communiqué. Paris: UNESCO.

UNESCO. (2009b) Thematic studies synthesis. Realized in the context of the task force for higher education in Africa. Paris: UNESCO.

United Nations. (2010). Draft plan of action for the second phase (2010-2014) of the World Programme for Human Rights Education. Retrieved September 3, 2017, from http://www2. ohchr.org/english/bodies/hrcouncil/docs/15session/AHRC.15.28_en.pdf.

United Nations. (2012) The future we want. Retrieved September 3, 2017, from: http://www.un. org/es/comun/docs/index.asp?symbol=A/RES/66/288\&referer=, http://www.un.org/es/ sustainablefuture/\&Lang=E.

Usher, A., \& Savino, M. (2006). A world of difference: A global survey of university league tables. Toronto: Educational Policy Institute.

Usher, A., \& Savino, M. (2007). A global survey of university ranking and league tables. Higher Education in Europe, 32(1), 5-15.

van der Wende, M. (2008). Rankings and classifications in higher education: A European perspective. In Higher education: Handbook of theory and research (pp. 49-71). 
Vlăsceanu, L., Grünberg, L., \& Pârlea, D. (2004). Quality assurance and accreditation: A glossary of basic terms and definitions. Papers on higher education. Bucharest: UNESCO.

Westerheijden, D. F., Beerkens, E., Cremoni, L., Huisman, J., \& Kehm, B. (2009). The first decade of working on the European Higher Education Area. The Bologna process independent assessment. CHEPS, INCHER-Kassel and ECOTEC.

Open Access This chapter is licensed under the terms of the Creative Commons Attribution 4.0 International License (http://creativecommons.org/licenses/by/4.0/), which permits use, sharing, adaptation, distribution and reproduction in any medium or format, as long as you give appropriate credit to the original author(s) and the source, provide a link to the Creative Commons license and indicate if changes were made.

The images or other third party material in this chapter are included in the chapter's Creative Commons license, unless indicated otherwise in a credit line to the material. If material is not included in the chapter's Creative Commons license and your intended use is not permitted by statutory regulation or exceeds the permitted use, you will need to obtain permission directly from the copyright holder. 